\title{
25 Research Square \\ Cytoplasmic translocation of p16 could be associated with CDK4 to promote progression of breast cancer
}

\section{Research}

Keywords:

Posted Date: January 25th, 2021

DOl: https://doi.org/10.21203/rs.3.rs-22345/v2

License: (c) (1) This work is licensed under a Creative Commons Attribution 4.0 International License.

Read Full License 


\section{Abstract}

The authors have requested that this preprint be withdrawn due to author disagreement.

\section{Full Text}

The authors have withdrawn this preprint from Research Square. 